Submitted: 24.10.2021 - Accepted: 22.12.2021

Year: December 2021 - Volume: 2 - Issue: 2

DOI: $10.47333 /$ modernizm.2021273789

\title{
THE AGE OF ICONICAL PROLIFERATION: POSTMODERNIST WORKS IN THE VALENCIAN ARCHIVE OF DESIGN ${ }^{1}$
}

\section{Vicente PLA-VIVAS ${ }^{2}$}

\begin{abstract}
The Arxiu Valencià del Disseny (Valencian Archive of Design; Spain) has among its collections a wide amount of records illustrating the works of designers such as Eduardo Albors, Paco Bascuñán, José Juan Belda, Pepe Benlliure, Lola Castelló, Silvia García and Vicent Martínez. These authors achieved international recognition during the last two decades of the $20^{\text {th }}$ century, when a shift from modernist to postmodernist paradigms emerged with a sheer intensity in design. Sketches and drafts often document the projects from that era showing their creative processes as works in progress. Analysis of these records revealed the following prevalent features. First of all, the iconical proliferation present in graphic, industrial and interior design endows these creations with remarkable expressive power, some distinctive personal poetics and compelling connections with modern art. Secondly, the transference of iconical components from decoration to structure challenges the preconceived assumptions on semantics and ontology of the designed objects, compatible with a strong sense of functionality. Finally, the hyper-iconical burst in postmodernist design contributes to the setting of highly hybridised visual environments in which concepts of public, private, natural and artificial surroundings interplay to send complex and contradictory messages. Beyond the significance for the culture of design, the cases of study addressed in this study could be read as manifestations of some cultural trends: the blurring of the borders between art and industry, the calling into question of biopolitical relations between individuals and their habitats, and the emergence of postmodernists ideologies in the core of an activity grounded on modernist principles.
\end{abstract}

Keywords: Postmodernist Design, Spanish Design, Visual Culture, Hermeneutics of Design, Contemporary Aesthetics

\section{THE ROLE OF DESIGN WITHIN THE POSTMODERNIST CULTURAL FRAME}

In 1852, The Illustrated Exhibition and Magazine of Art, a London magazine born in the wake of the 1851 Great Exhibition, proclaimed design as the centrepiece in production processes that endowed objects with real use value: " $\cdots$, no one will question the fact, that under certain circumstances a design executed even in common clay may be of more value than an object manufactured of massive gold." ("Art-Industry" 331). This concept on use value was shared even by Marx: "By this earlier formulation, in order to produce not mere products but commodities, a man must produce use values for others, social use values". (Appadurai 8). Due to its power to incorporate use value to commodities, design had a strong bond with Modernity since it was at the core of the master narrative of progress. It

1 This article has been produced in the frame of the Prometeo Research Project of the Generalitat Valenciana (2021-) Arxiu Valencià del Disseny: shaping the future, designing the present, rescuing the past.

2 Lecturer in History of Art, Universitat de València- Arxiu Valencià del Disseny, vicente.pla@uv.es ORCID: 0000-00027691-9254 
was supposed to work as one of the future world's foundations because of its rationalist, technical and projective essence. During the Arts \& Crafts era and the Bauhaus experience, design was required as a tool for the living standards' sustained improvement. The historical identification of design with the modern world, as it was supposed to be, was so intense than the former became a microcosm of the latter, a paradigm for the progressive ideals committed to the political project of Modernity: a collective effort to break humanity free from oppression. As Walter Crane expressed in 1898:

If we realize the close and necessary links that unite all workers, that are essential to the production of things useful or beautiful, or both, should not we do well to strive to make the association closer and more complete than it is, and thus hand on the lamp of good tradition in design and workmanship, however far we must look forward to the enlargement of our horizon and the harmonizing of human life, and its freedom from the sinister powers and false ideals that now oppress and deceive it? (Crane 373)

Crane was thinking from the marxist conceptual perspective on fetishisation of commodities but also of labour: "... he [Marx in Das Kapital] is trying to explain a fetishization of exchange value and not an object. The commodity could also be labor." (Carpenter 66). Either in the form of the value added to commodities or to labour, design embedded itself in the modern conception of progress. For a long time it seemed capable to provide and fulfil the modernist ideals: coherence between form and function, improved reliability for every produced object, universality and commitment to social equality. In a seminal essay on design issues, Vilém Flusser drew our attention to the modern meaning of the word design forged through the technical operative proficiency and linked to the cultural fate of the human race:

This is the design that is the basis of all culture: to deceive nature by means of technology, to replace what is natural with what is artificial and build a machine out of which there comes a god who is ourselves. In short: The design behind all culture has to be deceptive (artful?) enough to turn mere mammals conditioned by nature into free artists.

This is a great explanation, is it not? The word design has come to occupy the position it has in contemporary discourse through our awareness that being a human being is a design against nature." (Flusser 19)

But Flusser continued his reflections by bearing in mind the ultimate results of the 
modernist technological proficiency sense in our cultural and social appreciation schema:

Unfortunately, this explanation will not satisfy us. If in fact design increasingly becomes the centre of attention, with the question of Design replacing that of the Idea, we will find ourselves on uncertain ground. To take one example: Plastic pens are getting cheaper and cheaper and tend to be given away for nothing. The material they are made of has practically no value, and work (according to Marx, the source of all value) is accomplished thanks to smart technology by fully automatic machines. The only thing that gives plastic pens any value is their design, which is the reason that they write. This design represents a coming together of great ideas, which -being derived from art and science- have cross-fertilized and creatively complemented one another. Yet this is a design we don't even notice, so such pens tend to be given away free -as advertising, for example. The great ideas behind them are treated with the same contempt as the material and work behind them. (Flusser 19-20)

Flusser perceived the conceptual shift that took place during the last decades of the twentieth century. That shift affected the basis on which design had been deemed and allowed it to become the core of the Visual Culture paradigm of Postmodernity. What happened then to prompt that conceptual U-turn concerning design? Postmodern approaches to design started to dig deep into the concealed contradictions of Modernity. The early stages of this shift can be traced to the early stages of a "transition phase" in which: “... a broad, complex social learning process by which everything that belonged to the mainstream way of thinking and doing in the twentieth century will have to be reinvented." (Manzini 53).

\section{Design in the Lap of Postmodernity}

As if a programme of change was spreading through all branches of design and architecture, misplaced or even superfluous components started to appear in functional objects. The focus of modern design on collective progress was jeopardised by encouraging new interactions between the individuals and their commodities. A myriad of designed products conveyed the users' subjectivities from rationality to absurd humour, anxiety or neurosis. Consumers might even have doubted if a particular object was designed "... from the intention to create a member of that artifact kind." (Bloom 26). Many 
items displayed symbolical or allegorical meanings that modernist designers had strived to cast away from the strictly useful features. A flood of historical revival retrieved longforgotten ornamental traditions and artistic styles and confronted the basis of International Style, as cultural specificities strongly diverged from the modernist patterns:

The postmodern attitude assumes trivial matters and abandons the work's supposed universalizing significance. We are no longer looking for the essence of a work, but a transcription of a state of the world to a given moment knowing that this moment is not the one that is experienced on the other side of the world, will not be the same in the future, and that its transcription in the near past (or a historical filiation) is in fact excluded. (Alcalde 101).

Therefore, the idea of universal homogeneity and that of the linear progress collapsed, while the confusion between art, industry, popular culture and extravagant products increased to exorbitant levels and triggered passionate debates:

From its earliest incarnations, postmodern design was a subject of contentious debate. Everyone had an opinion about it; it was simultaneously applauded and derided, embraced and rejected. In combining sophisticated concepts with pop culture references, it was the first recent style to be both elitist and egalitarian, mixing high and low in the characteristic duality that its progenitors called "double coding", a term suggesting that there is more than one way to look at a building or an object. In allowing unfettered free expression, however, Postmodernism encouraged self-indulgent designs that sometimes descended into revivalism and kitsch;... (Gura 12)

The postmodern design was ill-considered from its very heyday. It was assumed to be the driving force for nihilism and a symptom of the lack of social commitment and politically engaged criteria. These were the characteristic features of the conservative revival. They promoted the depredatory and speculative side of the capitalist system that dodges the governments' control. In the words of Kevin Power, the postmodern tide worked as a fully and globally imposed harmful historical condition rather than as a style:

I happen to believe that we are before a cultural, political and economic transformation in western society and a change in sensibility for which at the moment there is no more appropriate term that Postmodernism. The 
nature and depth of the transformation remain debatable but nobody can dispute that there are major shifts involving the end of ideologies, the death of the subject, the contamination of high culture by low (not simply the kind of borrowing or quoting that characterized Modernism) and the totally different geo-political, not to say ecological, situation. (Power 149)

The Memphis group of designers pioneered the new trends in product and interior design during the eighties. They often devised their provocative and almost useless pieces of furniture as flashy, spectacular, exclusive or limited edition works of art than as humble and serviceable items meant for everyday use: "Memphis showed that innocuous, domestic things - sideboards and teapots - could play a part in the hyper-real life of the postmodern subject: a life lived as if always on stage." (Adamson, Pavitt 50). The approaching attitude to design from Memphis designers like Nathalie Du Pasquier, Shiro Kuramata, Michele De Lucchi, Aldo Cibic, Martine Bedin, Peter Shire or Massimo losa Ghini, as well as from other rising stars of the era like Javier Mariscal, Nigel Coates or Philippe Stark, fostered that negative perception of design. Their works, tagged as tongue-in-check, fanciful, inconsistent and expensive proposals, were allegedly oriented to whealthy and extravagant consumers eager to flaunt their social and economic status. David Harvey called this the "casino capitalism" and listed the design as one of its most emblematic manifestations related to the Yuppie culture:

Casino capitalism had come to town, and many large cities suddenly found they had command of a new and powerful business. On the back of this boom in business and financial services, a whole new Yuppie culture formed, with its accoutrements of gentrification, close attention to symbolic capital, fashion, design, and quality of urban life. (Harvey 332)

In this passage, Harvey tackled the structural role of design in the postmodern urban dynamics as a medium that was just available for a privileged social group and coveted for the rest: "Conspicuous leisure and conspicuous consumption become social norms for members of the leisure class, while at the same time, lower classes emulate." (Papageorgiou, Michaelides, and Bögenhold 722). Here design means, beyond doubt, all the stuff done by trendy designers, available through expensive shops, and only affordable to wealthy consumers. Acquiring designed fashion products was the equivalent of investing in commodities as they were supposed to work as a status mark, and high profits were expected. In the postmodernist sociological context, the word design meant the material 
outcomes as well as the means to produce them. Harvey stuck to the plan fixed a long time ago by Thorstein Veblen in The Theory of the Leisure Class, first published in 1899: "Even in articles which appear at first glance to serve for pure ostentation only, it is always possible to detect the presence of some, at least ostensible, useful purpose;..." (Veblen 100). And the essence of this line of reasoning still stood in the Pierre Bordieu work Distinction. A Social Critique of the Judgement of Taste (appeared in French for the first time in 1979) where the author addressed the links between the artistic taste and the culturally consolidated ways to enact social status:

The logic of the functioning of the fields of cultural-goods production, together with the distinction strategies which determine their dynamics, cause the products of their functioning, be they fashion designs or novels, to be predisposed to function differentially, as means of distinction, first between the class fractions and then between the classes. The producers can be totally involved and absorbed in their struggles with other producers, convinced that only specific artistic interests are at stake and that they are otherwise totally disinterested, while remaining unaware of the social functions they fulfil, in the long run, for a particular audience, and without ever ceasing to respond to the expectations of a particular class or class fraction. (Bourdieu 233-234)

\section{Design as an Aesthetic Experience in the Whirlwind of Contradictions}

Sociological approaches can still be used to reconstruct the postmodernist relation between design and aesthetics. Harvey also employed the term design in other parts of The Condition of Postmodernity. In the first chapter of the book, "The passage from modernity to postmodernity", the Schematic differences between modernism and postmodernism listed a series of concepts related to modernity in contrast with their postmodern counterparts. In the modern column, the noun design appeared in the fourth position opposing its postmodern antonym: chance (Harvey 43). We rarely see the postmodern designed objects as the outcomes of strictly rational thinking. On the contrary, we often judge them as the results of accidental, improvised, unforeseeable and chaotic designing processes. We regard these works as the consequences of a defective design. So, the word design itself falls apart into two mutually contradictory connotations. From theoretical and analytical point of view, the open gap between the modern and postmodern concepts of design seemed to threaten the semantic unity of the word unless we take into account the role of art in postmodern design. 
This leads to question the concept of design's ability to encompass two divergent semantic fields. The first field relates to the modernist categories of rationality, processual coherence, planning and full usefulness or objective performativity. The second field embraces the feeling of subjective perception, playful astonishment and aesthetic emotion. Postmodernist designers recaptured the last meaning. They focused on the artistic components of design by highlighting some strategic trickery that implies unpredictable creativity, polysemic symbolism, indetermination and contradictory effects triggered by thought-provoking artefacts. Let's go back to the etymological enquire driven by Flusser:

In English, the word design is both a noun and a verb (...) As a noun, it means - among other things - 'intention', 'plan', 'intent', 'aim', 'scheme', 'plot', 'motif', 'basic structure', all these (and other meanings) being connected with 'cunning' and 'deception'. As a verb ('to design'), meanings include 'to concoct something', 'to simulate', 'to draft', 'to sketch', 'to fashion', 'to have designs on something'. The word is derived from the Latin signum, meaning 'sign', and shares the same ancient root. Thus, etymologically, design means 'de-sign'. (Flusser 17)

It would be easy to identify postmodern design with the art of the late twentieth century for granted. But the relations of the postmodernist designing style with art were far more complex since the objects devised by the designers did not simply become works of art. Postmodern designers that craved for blurring the borders with art also tried to keep their specific mark on the commodities they produced. Back then, the design's artistic drift did not result from a radical transformation of designing methods into art-making but from the aestheticisation of the merchandise. And this is an ongoing process. In the words of Gilles Lipovetsky and Jean Serroy: "Designers, visual artists, fashion designers are invited to redesign the look of basic industrial products." (Lipovetsky, Serroy 22). According to Ernesto Francalanci, this process has a global dimension, deepens the culture of the spectacle, produces a strong homogenisation, and involves new challenges for the conscious mind that characterises the postmodern inculcation of the "diffuse aesthetic" in which:

The modern link which related the object produced aesthetically (the design) with a sensitive subject vanishes in making any merchandise aesthetically interchangeable. The subject, facing the widespread and homogeneous aesthetic, has been made absent, deprived of the faculty of 
judgment, of the possibility of choice, that is, of criticism. Advertising does not convey truth or meaning's horizon. The product is now fully accomplished in the strategy of its triple conversion into a spectacle: attraction, foreshadowing, symbolism. The diffuse aesthetic has the power to resolve and smooth the conflicts underlying each of these knots: the ethics of production, the ethics of communication, the ethics of use. (Francalanci 67-68)

\section{Iconicity and Aestheticisation in Valencian Postmodern Design}

It was during the decade of the eighties when the Spanish region of Valencia emerged as one of the roaring centres of European design: "... a key area for the development of industrial design in Spain as a discipline." (Martínez, Pastor, and López 47). It was thanks to a group of young creators who started working in design during the seventies, when this activity was not yet fully acknowledged in Spain as a professional career, that the Valencian design gained a brand reputation:

The members of this pioneering generation came, in most cases, from the schools of Arts and Crafts and the Fine Arts colleges. They showed an insatiable intellectual curiosity and great self-taught determination when it came to training as designers and, at the same time, building the foundations of a profession that, up until then, did not exist at all in the Valencian Community. It was they who, with the quality of their work, began to create the Valencian design brand;..." (Marín 208)

The aim of this study is not only to recall the importance of the contributions of this generation but to highlight the fact that some designers that started their careers under the influence of modern rationalist paradigms obtained their professional prestige during the worldwide peak of the postmodern designs. The role of this generation in implementing the previously described transformations is relevant since this group of authors represents a wide range of virtual and practical implications activated by the postmodern approaches to design. Moreover, they could serve as a demonstration of the idea of design as an activity that transcends usefulness by creating significance. As expressed by Dora Giordano: "The designers must operate with forms, specify them materially to respond to a function as a requirement for the user. Their contribution on the plane of significance will transcend the technical-scientific operability and instrumentality." (Giordano 134)

In the core of this significance lays a common ground for all these designers: the 
ways they create new icons and how they interlink the devised figurative elements with the semantics already present in the objects as an iconical load that the typologies to which they belong have received from tradition. Visual Culture theoretical approaches, methods and hermeneutics are no longer external to design as long as we can detect how the authors endowed their creations with their imaginaries and intentions. Moreover, this new burden of significance shall find those of the users and receivers. Guy Julier claimed the inability of the Visual Culture sensibilities to deal with design issues compared to the Design Culture based models: "To embrace Design Culture as an academic discipline requires, therefore, a different sensibility than that of Visual Culture." (Julier 76). But this is not about the extent to which the academic perspectives based on Visual Culture interpretative frames can perform at the service of design. What we are mainly concerned here is how Visual Culture involves in the creative designing processes, how does it work to foster symbolic associations, emotions, remembrances and even behavioural patterns in receivers. The aestheticisation of the objects by increasing their iconicity and creating hyper-figurative objects has its roots in artistic processes. The effects of the same creations in the consumers, owners or spectators minds and habits belong to the logics of contemporary art. Dejan Sudjic remarked on the art-design active connections in the nowadays world:

Design has always involved shaping or embellishing everyday things, to provide us with a reminder of the world beyond utility. It is intimately concerned with the emotional character of objects. Design is used to make things that are cheap to produce seem expensive. It makes products look rugged, and therefore glamorous, even when they are flimsy. Why can't it also make banal objects that look like art, even if perhaps they aren't?

Most designers have been trained to believe that design is not art. Perhaps that is why they so often try to be artists. George Nelson, for example, one of America's more cerebral industrial designers, claimed that "the designer is in essence an artist, one whose tools differ somewhat from those of his predecessors, but an artist nonetheless". (Sudjic 98)

\section{Integrating Iconicity: From Decoration to Function}

Our first case of study tackles some well-known works of two Valencian designers who collaborated for many years: Lola Castelló (b. 1947) and Vicent Martínez (b. 1949). 
They both started their professional careers during the seventies and shared an interest for the most depurated designing styles (like those of the austere European schools of design). This modernist and strictly functional approach to design was the inspirational force for their first collaborative job for the Grupo Huella (Footprint Group) and the Grup Nuc (Knot Group), (the latter in association with the designer Daniel Nebot and the businessman Luis Adelantado). However, their more prominent contribution came to light thanks to their skills in merging the functions of designers and entrepreneurs, creating, managing and designing for their furniture factory Punt Mobles. Their works between 1985 and 2010 allowed Castelló and Martínez to achieve their reputation as designers by merging their initial talents for creating highly functional, austere and affordable pieces of furniture with some new iconic and expressive elements:

Punt Mobles became a company with a strong influence on other professionals in the sector. Having your own company to produce your own designs and decide what furniture to make was, and still is, the dream of many designers. It was also influential among other entrepreneurs who saw how design added a differential value shown in the quality of its products, in the coherence of their collections, and in the values it communicated. (Martínez 121)

In the wake of the postmodern flood spreading throughout the field of design during the eighties and the nineties, Castelló and Martínez gave birth to their more accoladed contributions to design. La Literatura (The Literature), designed by Martínez in 1985, was a groundbreaking concept of a rack of shelves arranged in two levels of depth that obtained a massive commercial success. The rack in the foreground is mounted on wheels and slips over a rail allowing access to the rack in the background. There is an iconical element in the immediate connotation of the mobility of a train in La Literatura. Even a funny connotation of the idea of a children's play, like in the also famous Super Lamp of Martine Bedin for Memphis (1981).

But maybe the most obvious resort to iconicity, as far as the work of Vicent Martínez is concerned, was his imaginative and surprising way of revisiting the typology of the extendable table, previously addressed under modernist perspectives by designer Hendrick Wouda in the thirties. With Anaconda (1989) - fig. 1 - Vicent Martínez reached a brand new solution by devising a system of a shutter, like the ones used for the windows, hidden inside the beams that supported the table board, and able to be stretched horizontally up to different lengths by pulling from the edge of the table board. The drafts made during the 
creative process of Anaconda (preserved in the collection of the Valencian Archive of Design) show the source of inspiration for Vicent Martínez in a very explicit form. The designer drew a snake in a naturalistic manner. The suggested creeping movement of the animal is in graphic relation to the innovative technical solution for the table. The icon is transferred from decoration to function. Moreover, we have to bear in mind all the meanings precipitated by introducing unexpected natural elements into the domestic realm of daily life: a tropical snake into the dining room is "... a semantic pairing in the sheerest form." (Rambla 47). The danger associated with the harmful animal could be interpreted under a hermeneutic perspective as though the author wanted to recall something akin to an apotropaic psychic mechanism: keeping the danger under control, transforming the iconical motif into a structural and serviceable element, and thereby assigning fully functional features to an exotic and decorative icon.

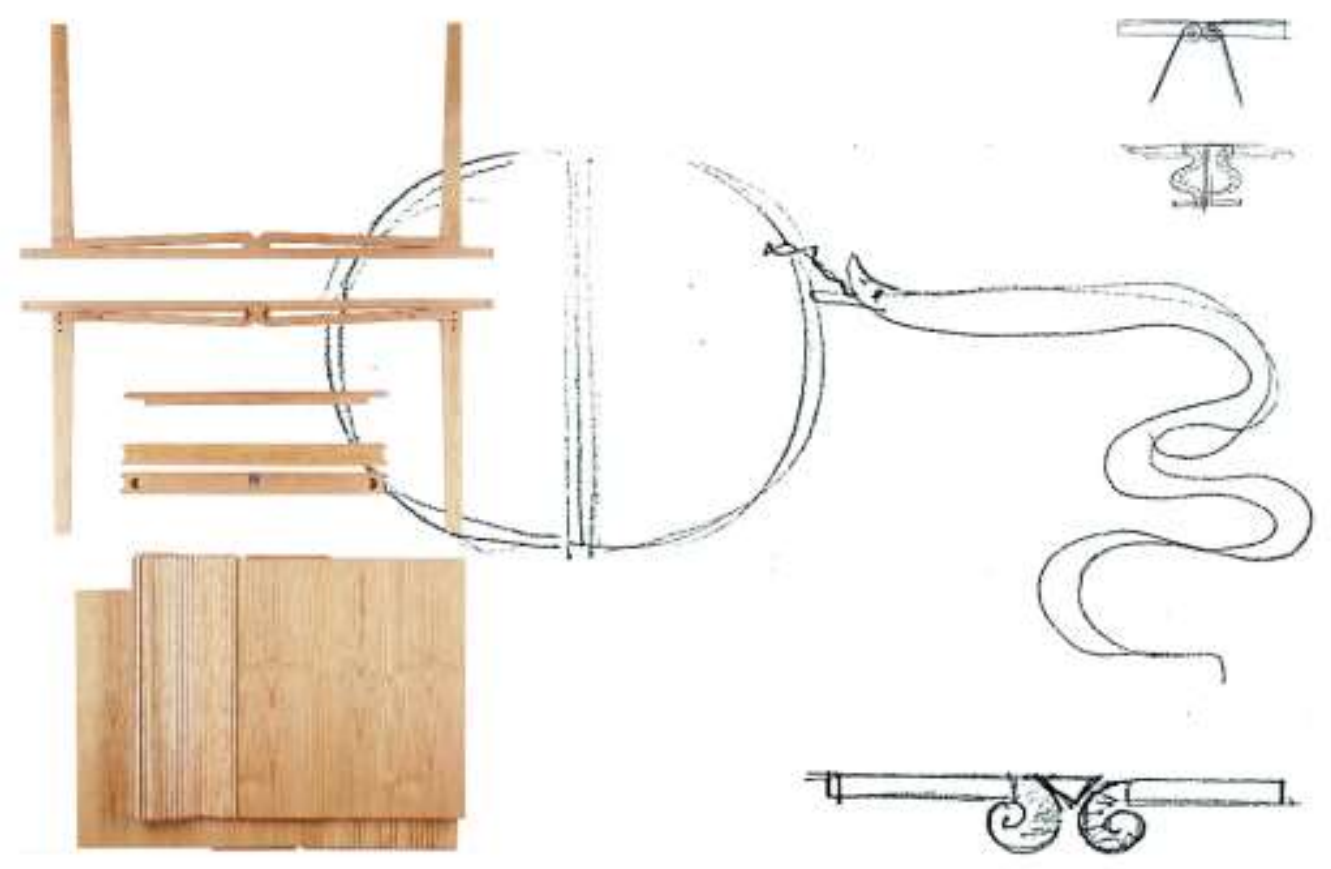

Figure 1. Vicent Martínez: Anaconda table (Punt Mobles, 1989)

- Arxiu Valencià del Disseny -

Another production for Punt Mobles also employed an iconic motif as a thematic inspiration to enhance the object's functionality. The table Papallona (Butterfly) - fig. 2 was a co-authored creation of Castelló and Martínez dated in 1991. It consisted of a wooden table prepared to acquire two configurations. It has the aspect of a conventional 
dining table when the round tabletop unfolds. When folded, this piece of furniture turns into a console table that is placeable just against the wall. Increasing furniture's capability was nothing new but achieving a high degree of functionality through driving the figurative inspiration in nature to a brilliant mechanical solution was a worthy innovation. The shapes of the brackets connecting the legs to the top mimic the wings of butterflies as an iconic sign. Both structural elements can rotate to support the circular surface of the top of the table or just half of it if the other half remains stuck to the wall. The experience of movement enhances the iconicity of the brackets. Thanks to the hinged folding mechanism in the upper central joint, the tabletop also acts as another iconic sign by suggesting the formal symmetry and the articulated motion of the butterfly wings. The double functional features of the table correspond to a duplicated iconical relationship between the table and its natural referent. There seems to be a contradictory interplay between the notion of stability inherent in the semiotics of the table and the experience of mobility when manipulating the object. Nevertheless, the symbiosis between natural/cultural realms and table/console typologies extends the signification of this piece of furniture from double semantics to double semiotics.

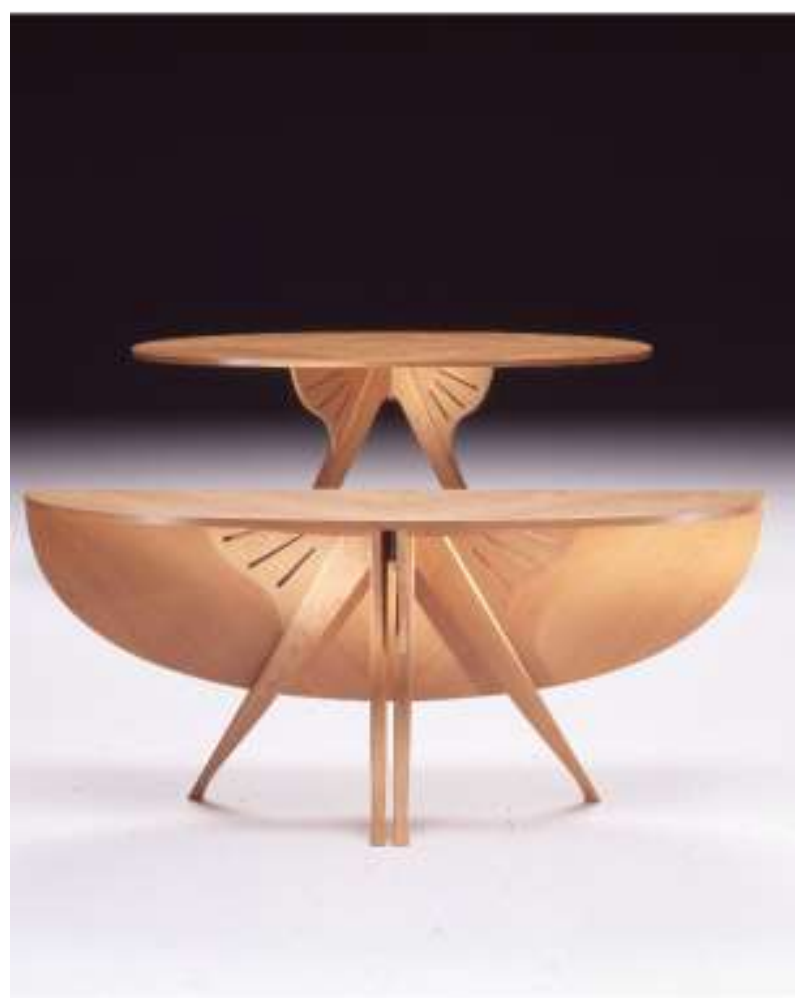

Figure 2. Lola Castelló and Vicent Martínez: Papallona table (Punt Mobles, 1991)

- Arxiu Valencià del Disseny - 
Lola Castelló authored another design for Punt Mobles: the table Carmen (1990) fig. 3 -. According to Josenia Hervás and Silvia Blanco, Castelló “... has managed to combine creative genius with commercial proposals, with warm and even sinuous lines." (Hervás, Blanco 43) Nonetheless, for Castelló sinuosity was not intended to be an appealing resource to foster the commerciality of her design, at least as Carmen is concerned, because of this table:

“... had a round board supported by suggestive curved legs that invite one to think that the table could start moving by itself at any time. Its creation was inspired by a photograph of the homonymous ballet staged by Antonio Gades. In it, the actress Cristina Hoyos danced in this version of the known myth created by Prosper Merimée which inspired Georges Bizet's opera. The undulations on the skirt of this actress were captured in the legs of the Carmen table." (Martínez 113)

The wavy shapes of the boards connecting the four legs are the most prominent feature of this piece of furniture. On the one hand, considered under strictly functional criteria, they give solidity to the supporting structure while providing enough room in the lower part for the feet of those seated around the table. On the other hand, Carmen is another example of how iconical inspiration can merge with functionality, as the sinuosity emulates the motion of the clothes of a flamenco dancing woman. Despite some formal analogies of Carmen with the Alessandro Mendini's Macaone table (1985), in the creation of Castelló figurative and practical sides work together in this postmodern design that encapsulates historical references and semantic contradictions between stability and dynamicity. Carmen is a model of iconical integration into functional features that still keeps alive some modernist principles of design:

Decoration, or ornament, we have been too much accustomed to consider as accidental and unrelated addition to an object, not as an essential expression and organic part of it; not as a beauty which may satisfy us in simple line, form, or proportion, combined with fitness to purpose even without any surface ornament at all. (Crane 90) 

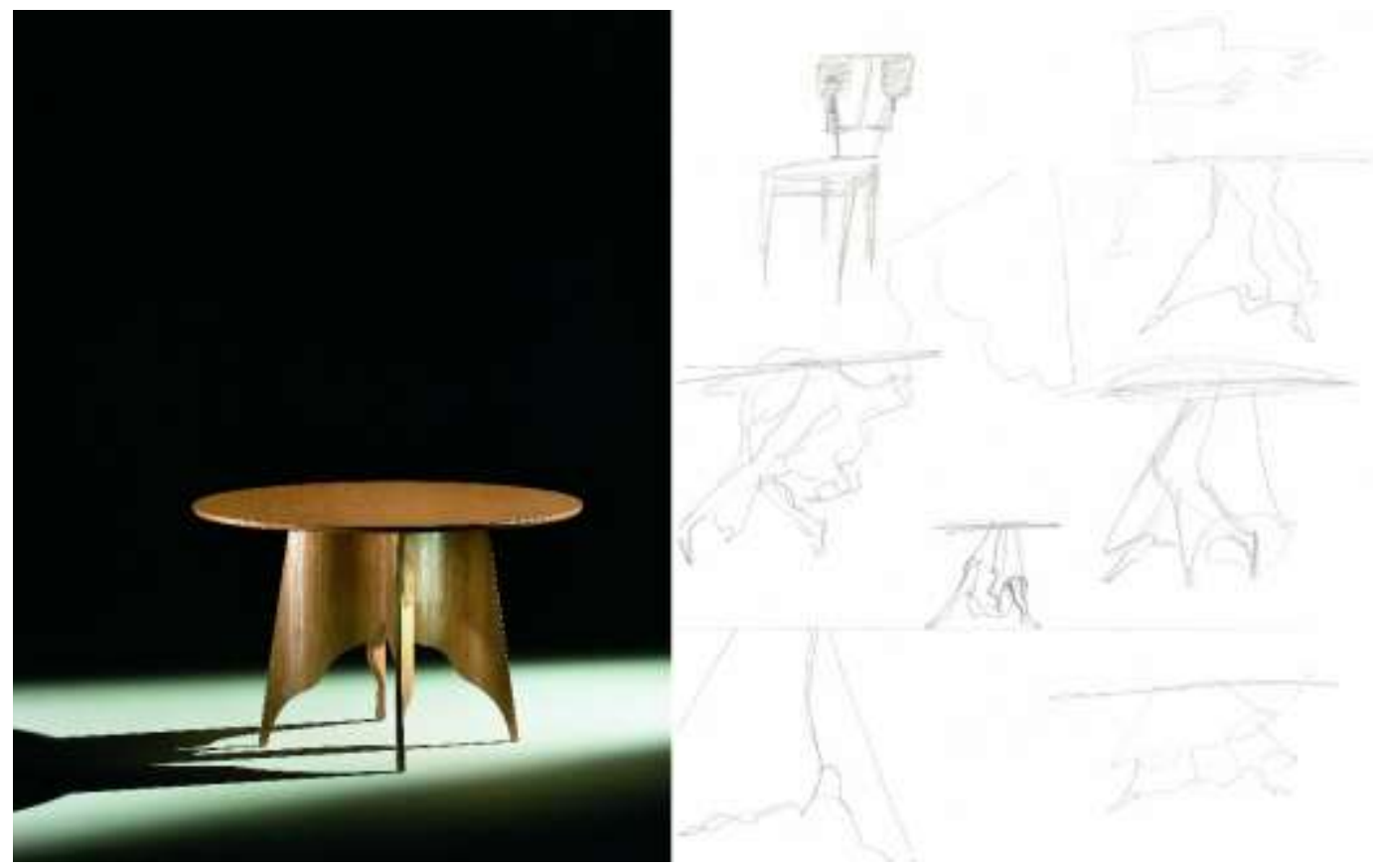

Fig. 3. Lola Castelló: Carmen table (Punt Mobles, 1990)

- Arxiu Valencià del Disseny -

\section{Icons for Hybridations: Playful and Distressing Bodies}

There are two authors whose works are in the Valencian Archive of Design: José Juan Belda (1947-2021) and Eduardo Albors (b. 1949). Both of them pioneered the collaborative approach to design by creating two groups of designers that have been regarded as some of the cornerstones of contemporary Valencian design: the group Caps i Mans (Heads and Hands) in 1972 with Jorge Luna and Carlos Albert and the collective of designers La Nave (The Hall) 1984-1991 with Paco Bascuñan, Carlos Bento, Quique Company, Sandra Figuerola, Marisa Gallén, Luis González, Luis Lavernia, Nacho Lavernia y Daniel Nebot. Like Castelló and Martínez with Huella, Nuc and Punt Mobles, Albors and Belda acted as a driving force influencing many other designers during the decades of the seventies and the eighties.

José Juan Belda stood out as one of the most prestigious interior designers. His activity was frequently related to the creation of pieces of furniture. Belda invented the armchair Gong, with some formal analogies to Mario Botta's armchair Prince (1985) and Mosca (F/y) - fig. 4 - both in 1987 and commissioned by Luis Adelantado. The latter was a milestone in the career of Belda because he synthesised the iconic motif of the insect in a few and simple geometrical shapes endowing the object with a constructivist look. But the high degree of stylisation, instead of generating some abstract compositional 
air, suggests a strong analogy with the animal forms. The impression of being in front of an iconic sign is even more conspicuous when we notice the extreme lightness of the chair. Another enthralling source of inspiration and symbolic implications in Mosca is David Cronenberg's horror dystopic sci-fi film The Fly that became a blockbuster in 1986 . The movie narrates the gradual transformation of a scientist into an insect due to an experiment. Behind this story, based on the tale of George Langelaan, lays the influence of Franz Kafka's masterwork The Metamorphosis. Imbued in the postmodern aesthetics, Mosca was maybe the most accomplished design incorporating two circles to the upper section of the chair back. Some years ago, in 1981, Wendy Murayama had released a typical postmodernist tongue-in-cheek design blending highbrow cultural references (the prestigious architect and designer Charles Rennie Mackintosh) with the lowbrow culture icon Mickey Mouse: the obviously named Mickey Mackintosh chair. Another famous designer and close friend of Belda, Javier Mariscal, took a similar approach in 1987 when he released the Garriris chair, a variation of his cartoon characters inspired too by Mickey Mouse.
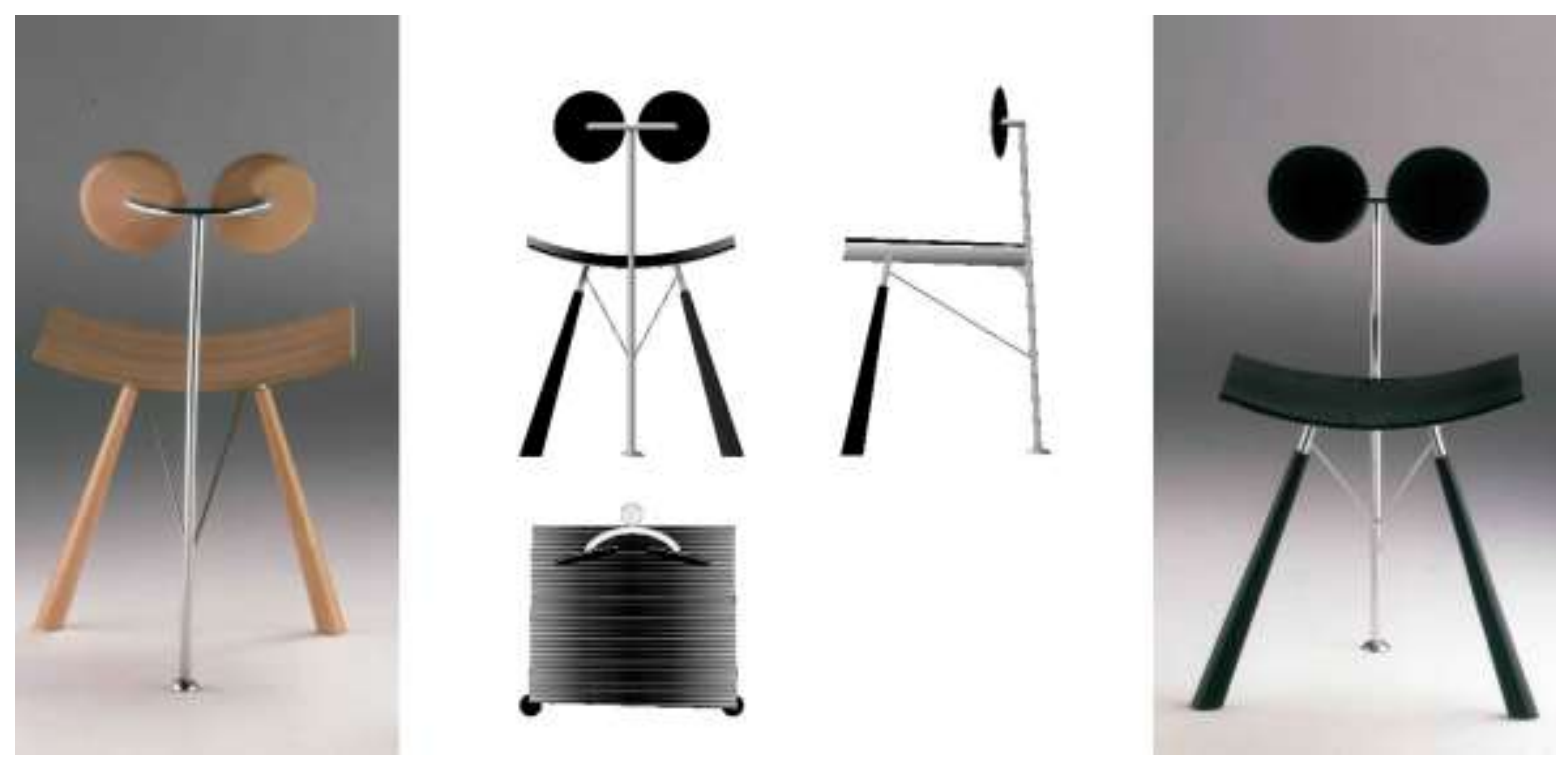

Fig. 4. José Juan Belda: Mosca chair (Luis Adelantado, 1987)

- Arxiu Valencià del Disseny -

In 1989 Belda created on his own initiative the chair Cebra (Zebra), also known as Catalina (Catherine) - fig. 5 -, commercialised by Om. The designer endowed the chair with iconical suggestions from different sources. The most evident is the exotic, wild, 
striped fur animal. But we can also bear in mind that Cebra can be related to Victor Vasarely's Op art and Gothic architecture since Catherine was a Catholic saint from Siena, whose cathedral shows all along arches and walls the decorative motif of black and white stripes. The way in which Belda uses iconicity grounds on hybridisation processes between geometrical and figurative forms and between objectual and organic (zoological) referents. Both chairs (Mosca and Cebra), meant to allow people to sit and rest, are virtually related to fast movement, which generates a contradictory interplay between physical stability and virtual mobility. His creations also prompt a feeling of unstable subjectivity since the users face uncanny identities as they can adopt the fantasy roles or either be metamorphosed into an insect or even riding a wild African animal. In the words of Belda during a conversation with Javier Mariscal:

For me, design has two very different fields. A technical one, in which strictness and functionality must prevail, as in the case of a tool, a wheelchair or an electrical appliance and another "sumptuous", such as a piece of furniture, a coffee set, a lamp...where ergonomics and technology can coexist, with the emotions. (Gámez, Yuwang 64)

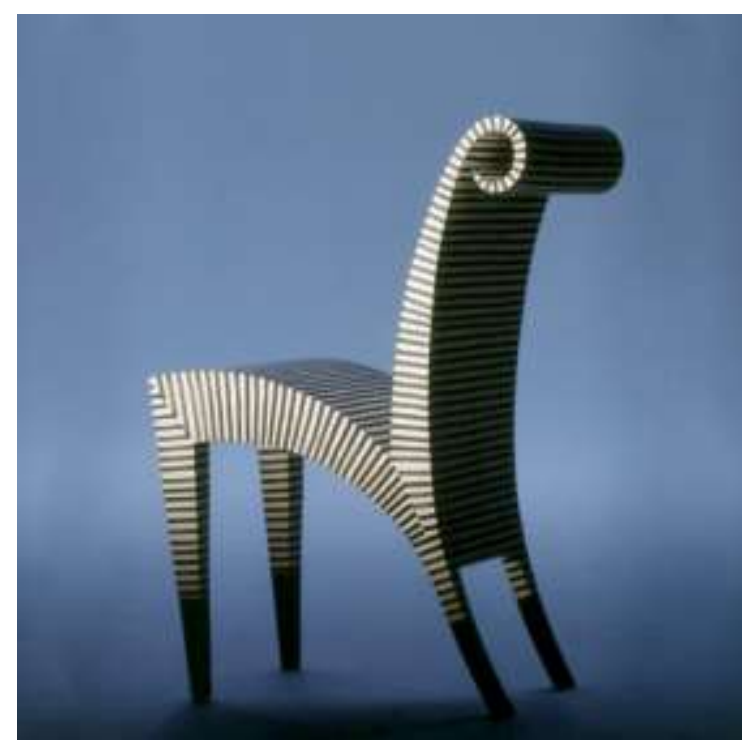

Fig. 5. José Juan Belda: Cebra chair (Luis Adelantado, 1987)

- Arxiu Valencià del Disseny -

Emotions coexist and even prevail in some designs, emotions like the unnerving feelings unleashed by two works of Belda and Albors through which they activated the powerful effects caused by human figure-based icons. José Juan Belda (1947-2021) released in 1993 one of his most perplexing creations: the chest of drawers Madame 
Pompidur - fig. 6 - produced by Acanto. The name is intended to be a pun about the historical character Madame de Pompadour and pompi dur, phonetically similar for people in Valencia (Spain) to the English expression hard-ass. Belda renewed some avantgardist precedents like the ones of the Marcel Duchamp puns (L.H.O.O.Q. or his nickname Rrose Sélavy) and Salvador Dalí: "In any case, the most direct reference to Madame Pompidurin the work of the surrealists is found in the Venus de Milo with Drawers (1936) by Salvador Dalí." (Gimeno 55). Indeed, this mutilated body draws on Surrealism but its anatomical forms are also fully functional since no space is lost or misused in decorations. While the curved shapes recall the capricious, sophisticated and dynamic Rococo style of the eighteenth century, almost every centimetre of this piece of furniture can be put to use as a drawer. Maybe the perception of the female body objectivation in such a highly efficient way adds to this hybrid item some ambiguous and sinister symbolic contents interplaying with the omnipresent humour. Is this a postmodernist prank or a partial redemption from the dark relations that modernism established with bodies?

Body in crumbs, fragmented body, body reduced to so many partial objects, the modern body seemed to manifest the regression to some previous state of the erotic development of the human soul, to some sadistic or paranoid stage that we encounter in youngest children, rather than this triumphant achievement of the future man whose avant-gardes would claim to give birth. (Clair 43)

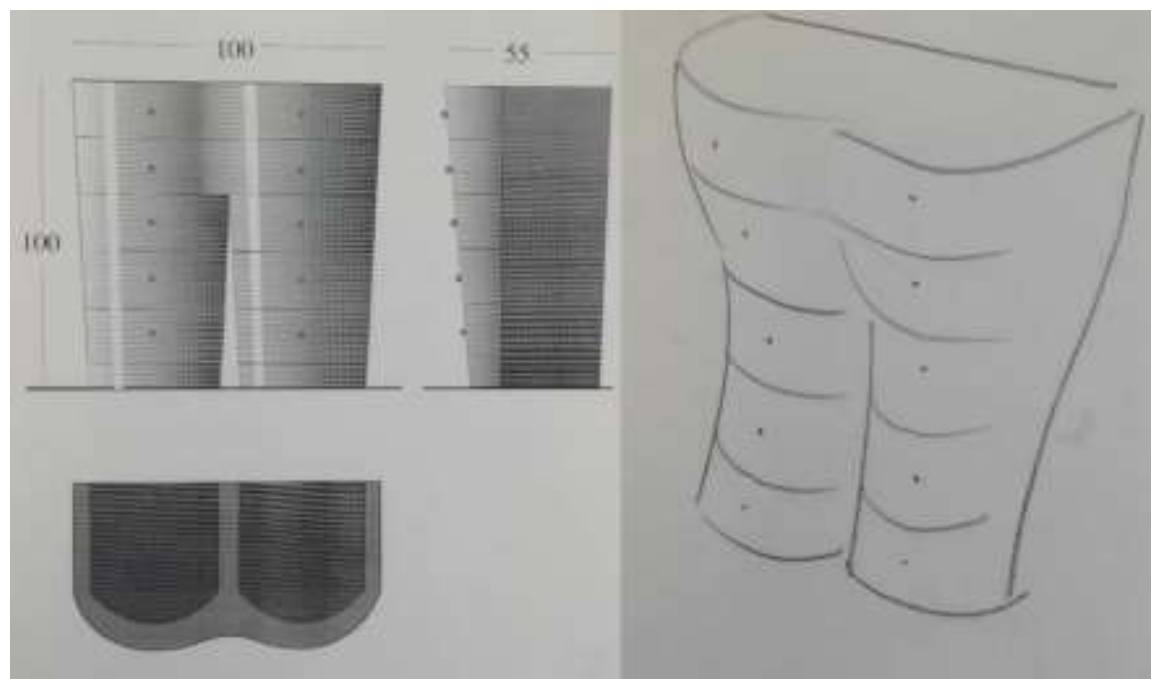

Fig. 6. José Juan Belda: Madame Pompidur chest of drawers (Acanto, 1993)

- Arxiu Valencià del Disseny -

Some years later, Eduardo Albors (b. 1949), well-known as a high-tech lightning 
appliances and equipment designer (but also furniture, toys and graphic design) took the female body as a source of inspiration. Previously, Albors had approached iconic motifs for the table lamps Antorcha (Torch), whose shapes clearly recalled a flame, and Sor (Sister, as is commonly applied to Catholic nuns) at the end of the eighties. But Mariola- fig. 7 -, produced by Celda in 2000, was arguably his most striking and controversial creation. It consists of a plasterboard stand and plastic shade in a life-size limited-edition floor lamp. The half figure of a young woman body represented from below the waist has strong analogies with some works of Pop art (Tom Wesselmann, James Rosenquist), hyperrealistic sculpture (John De Andrea, Duane Hanson) and comic (Milo Manara). Mariola merges art and popular culture in a typical postmodernist vein, and it does the same with some other references to older styles by recreating the female figure used in Tiffany's Art Nouveau lamps. Although, in this case, we can perceive the complete transference of the figurative icon from decorative to structural functions: the legs literally work as the stand and the skirt as the shade. Mariola conveys strong contradictory meanings and casts some doubts: it is an experiment pointing at the ontological status of the designed object, maybe an innocent joke or a symbolic sexual objectification of the female body? Specially if we considered the tendentious interplay with the owner/user due to the placement of the switch just in the inner frontal part of the short skirt - fig. 8 -.

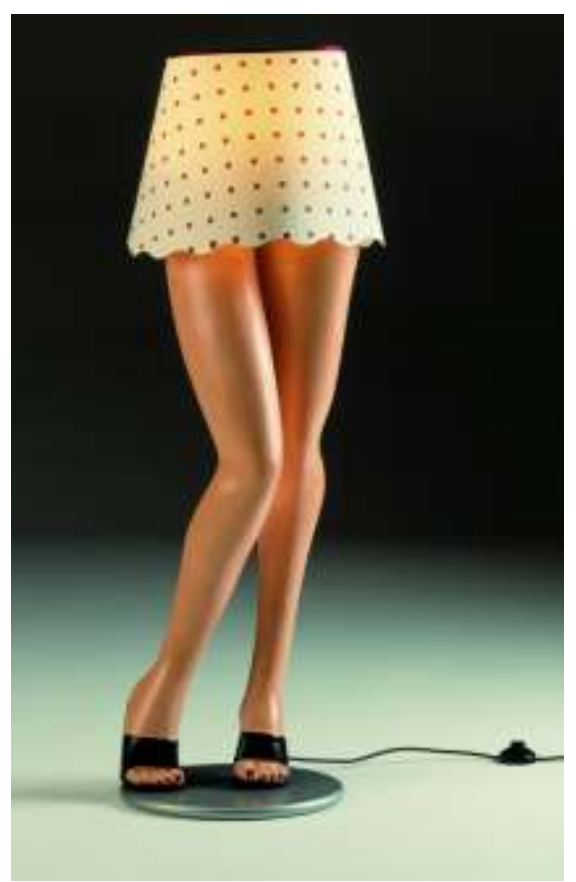

Fig. 7. Eduardo Albors: Mariola (Celda, 2000)

- Arxiu Valencià del Disseny - 


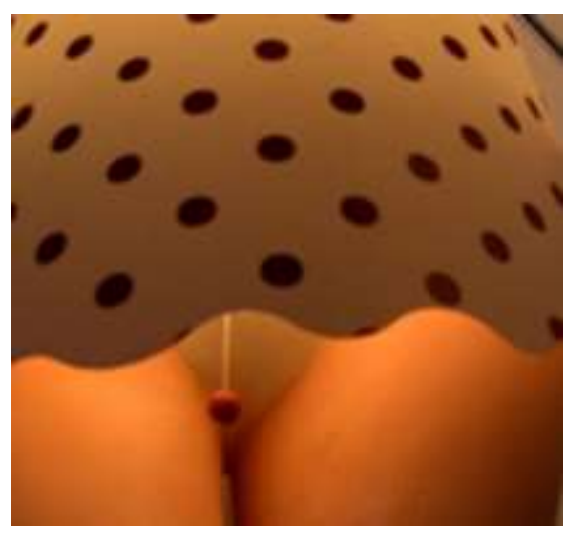

Fig. 8. Eduardo Albors: Mariola (detail of the switch)

- Arxiu Valencià del Disseny -

A series of questions prompted for Mariola arise: is it a childish mischief exercise or a serious attempt to destabilise the subjectivities of those who operate the object by forcing them to deal with ethical issues in practising trivial daily gestures like switching on and off a lamp? And still: did the author intend to amend the ontological status of the object? Furthermore, as far as Madame Pompidur and Mariola are concerned: were Belda and Albors acting as two faithful postmodernists dedicated to constraining the disturbing thoughts into the symbolic realm? Or maybe did they forecast, with their iconic motifs inspired but fully functional hybrids, the ontological turn?

The "ontological turn" in social theory is an emergent wave involving a variety of different disciplines, that attempt to take these thoughts of contingency, flux and difference from the realm of discourse and culture, where they have been confined by postmodernism, to the realm of matter. (...) ...hierarchies, identities and dualisms are replaced with fluid, contingent, emergent entities, with networks, relations, performances, materialisations, assemblages, human-nonhuman or organic-inorganic hybrids. (Christensen, Conradi 99)

\section{Displaced Icons: Familiar and Unfamiliar Uses and Spaces}

Other works documented in the Valencian Archive of Design can also be taken for the analysis of another characteristic feature of the postmodernist aesthetics set into practice through design: the generation of displacement feelings experienced either in space, time or both of them simultaneously; the abolition of the borders between public 
and private spaces; or between past and present times. If combined, these effects give rise to contradictory playful and disturbing biopolitical relations between individual and social subjects and their habitats. According to the conceptualisation of Michel de Certeau:

In our examination of the daily practices that articulate that experience, the opposition between "place" and "space" will rather refer to two sorts of determinations in stories: the first, a determination through objects that are ultimately reducible to the being-there of something dead, the law of a "place" (from the pebble to the cadaver, an inert body always seems, in the West, to found a place and give it the appearance of a tomb); the second, a determination through operations which, when they are attributed to a stone, tree, or human being, specify "spaces" by the actions of historical subjects (a movement always seems to condition the production of a space and to associate it with a history). (Certeau 118)

Therefore, spatial alterations caused by objects lead to a disorientation in the way we operate along with our existences in spaces: "Designers must always address the tensions around novelty and familiarity." (Bardzell, et al. 295). Design is immersed both in making new objects and in planning daily interactions that take place at familiar spaces:

Domestic systems of orientation, order, and arrangement articulate a repeated stylisation of the body that direct us towards normativity and comfort. This phenomenon affects how we move through and conceptualise our social reality. When lived identities and experiences are at odds with normative frameworks, disorientation and disidentification can occur. (Maher 45-46)

Silvia Garcia (b. 1962) took charge in the mid-eighties of the Design department of the cooperative glass and ceramics Spanish manufacturing company La Mediterranea. From this moment on, she and her team produced several series of tableware elements that boosted the exportations of the company and gained international prestige. According to the catalogues of the company, from 2005 to 2012, García and her team released a series of bathroom accessories made in transparent and coloured glass: Urban Fresh - fig. 9 -. The small size of the articles fits the narrow ledges of the reduced space of the most private room of every house. These tiny objects were designed to contain toothbrushes, toothpaste tubes, cosmetics, combs, soap bars and other little things that we use in close contact with our bodies. But the iconical motif for all of the Urban Fresh items was a big-scale object: the skyscrapers of the early modernist and rationalist American architecture. The 
inspiration is, beyond doubt, taken from the shape of famous and large edifices like the Danmark Adler and Louis Sullivan Wainwright building in Saint Louis (1890) and those that defined the urban landscapes in a metropolis like the ones of Chicago or New York. In Urban Fresh, the typical postmodernist resource to cultural historicity and the inclination, shared among the group of designers of this study, towards the integration of form and function. In this case, the embossed surfaces protect the slippery recycled-glass objects from accidental drops when manipulated with wet hands. Not to mention the coexistence of the form/function integration with the production of subjective effects triggered by placing a simulated urban landscape - the ultimate outdoor public space - in the private realm of the bathroom: the triple contradiction big/small, public/private and dirty/clean.

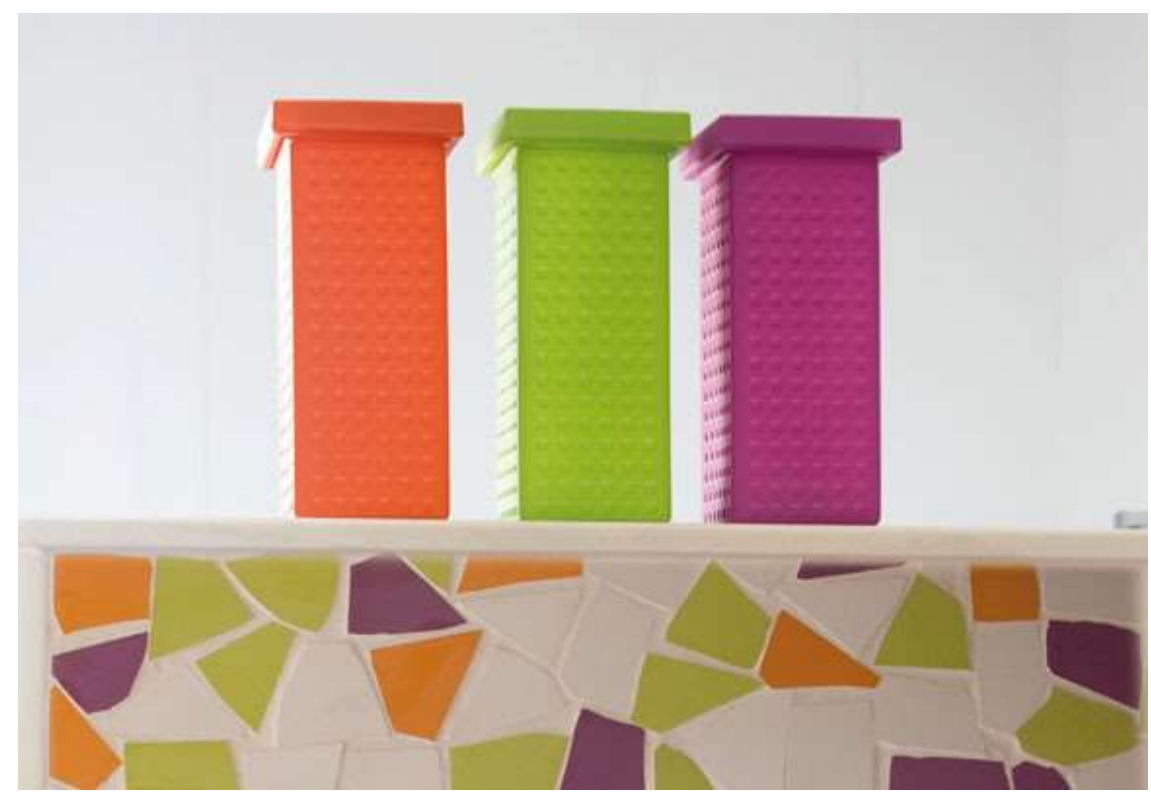

Fig. 9. Silvia García: Urban Fresh (La Mediterranea, 2005)

- Arxiu Valencià del Disseny -

Pepe Benlliure (1942-2020) was a designer professionally trained in the seminal workshop of José Martínez-Medina, who pioneered in modernist furniture making and interior design in Spain. The rest of Benlliure's career was devoted to creating the most elaborated pieces of furniture for the factory Baixauli. Although the factory was upmarketclassic-furniture-oriented (Val 35), Benlliure endowed his lavish creations with a postmodern touch by blending historical references to Art Déco style with his ability to design in a very personal, fantasy-prone and even oniric way. Around 1985, Benlliure 
designed a set of pieces of furniture for bedrooms, lounges and dining rooms with a clearly iconic inspiration: Mil bolas ( $A$ Thousand Balls) inspired by the elements of the pool game - fig 10 -. Like an obsession, the forms and figures of balls, sticks and pool tables were reproduced and adapted to side tables, dining tables, consoles, cupboards, wardrobes or beds, all of them meant to occupy almost every corner of the house. The designs of Benlliure got rid of the woodcut procedures, but some of his pieces of furniture still blended industrial and traditional craftsmanship processes since they were made of precious woods and required high-skilled workers able to deal with cabinetmaking and inlay techniques.
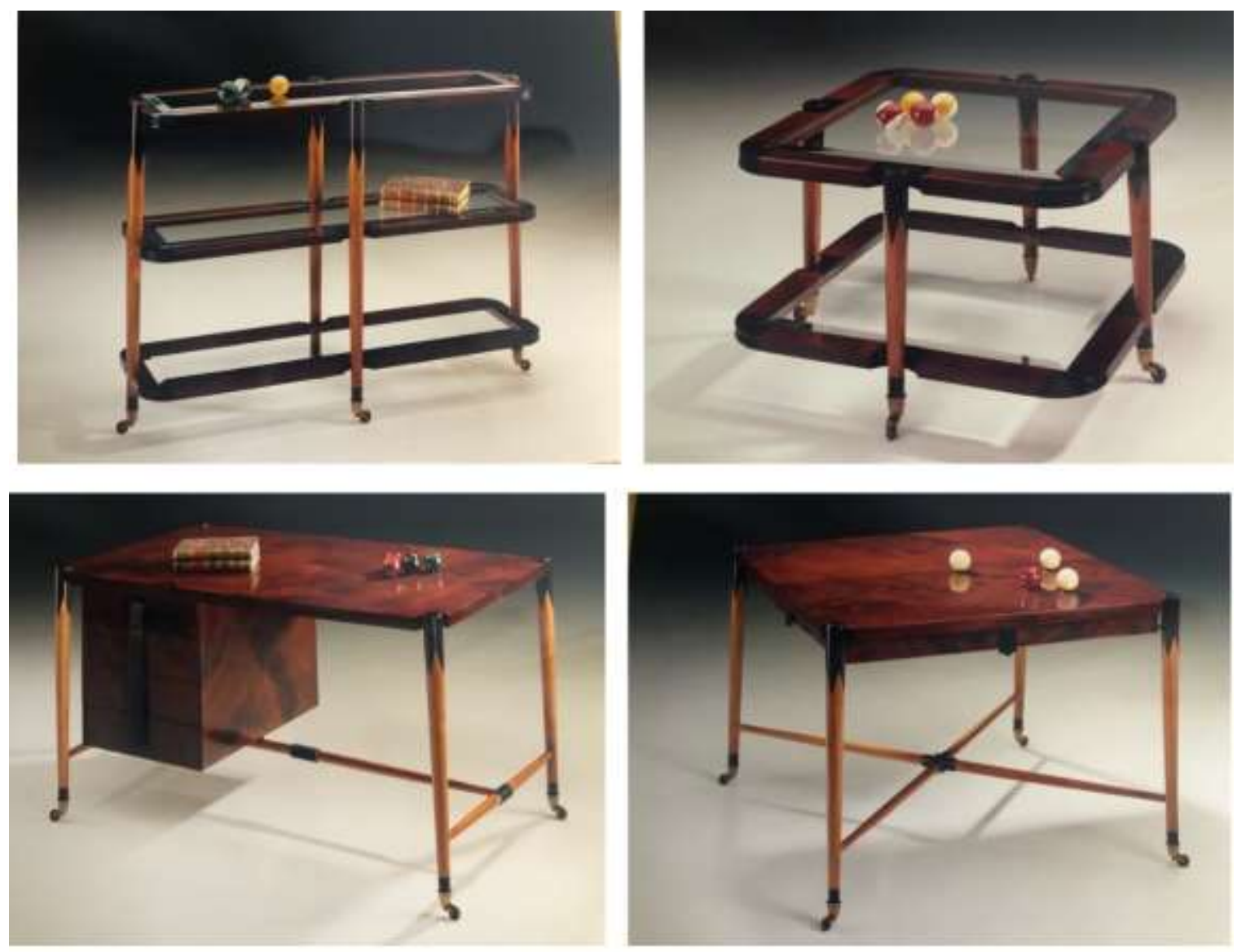

Fig. 10. Pepe Benlliure: Mil bolas pieces of furniture (Baixauli, c. 1985)

- Arxiu Valencià del Disseny -

With the Palmera (Palm) side table, designed a few years later c. 1990, - fig. 11 Benlliure also showed the same yearning to integrate the whimsical figurative motifs into structural elements, a procedure intended to resolve the contradiction between sophistication and functionality. He blurred the borders between public and private, between outdoors and outdoors spaces. He entangled the subjective perceptions and 
experiences of the daily domestic life with a dense net of ambiguous and unexpected suggestions: a ludic activity in every room of the house or a tree growing indoors from the floor. He put into practise the postmodernist conception of interior design: "What differs postmodernist interior space from the modernist space is that the modernism considered space homogeneous in every direction, abstract and rational whereas postmodern interiors are heterogeneous, irrational and ambiguous." (Güven 32-33).

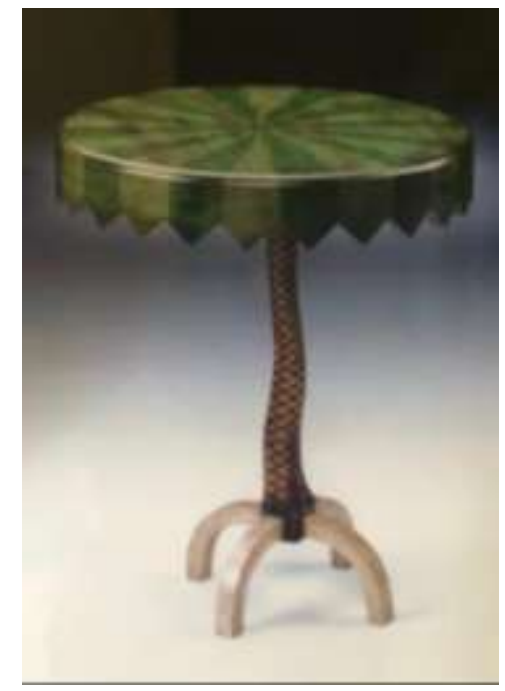

Fig. 11. Pepe Benlliure: Palmera side table (Baixauli, c. 1990)

- Arxiu Valencià del Disseny -

Paco Bascuñán (1954-2009) was one of the most acknowledged Spanish graphic designers. From his period in La Nave and forward, his work achieved a great diffusion thanks to its versatility, its academic dimensionn and the important commissions from public institutions. Moreover, the solid humanistic and artistic culture of Bascuñan gave reflection, meaning and purpose to his creations. It also allowed him to establish some interesting dialogues with modern art history: "It can be argued that Bascuñán uses a true eclecticism in his designs, that is, one originated from a deep knowledge of the history of art and the correct adequacy of media and ideas..." (Galán 20). He reinterpreted historical artworks by deconstructing impressionist and avant-gardist artistic resources. He adapted the artistic heritage in which he found inspiration to the new technologies and the massmedia dissemination methods. Moreover, through his institutional commissions (works of signage of roads and tram lines) and the advertising and media campaigns he carried out, Bascuñán transferred iconic models taken from well-known modern artists like Joaquín 
Sorolla and Josep Renau to the public sphere in a very postmodernist spirit:

During the last twenty-five years, he took up the postmodern mantle against the austerity of modern thinking. But for Bascuñan, the ornament was the starting point of a reflection on the need to personalize objects through marking them, which produces effects on the aesthetic pleasure and the human beings relationships,... (Pelta 27)

There are some graphic design works in the Paco Bascuñán legacy to the Valencian Archive of Design that can serve as examples of the postmodernist and expressive ways in which Paco Bascuñán conveyed iconic motifs taken from the tradition of the modern arts to generate time displacement feelings in brand new contexts. In 1989 Bascuñan received the commission from the Feria Muestrario Internacional (International Exhibition Fair) of Valencia for designing a Christmas greeting card - fig. 12 -. Instead of drawing on religious iconography, he took as a starting point a Juan Gris cubist still life painting dated in 1917 and now in the Minneapolis Institute of Arts. Bascuñan integrated the iconic motif of the guitar of Juan Gris in a new composition which brought back the aesthetic essence of Cubism combined with his new typography. Although the use for which Bascuñan devised his creation was quite different and even contradictory from that of the original artwork, the designer achieved an astonishing plastic coherence. He proceeded in similar ways when creating other Christmas greeting cards for 1990 and 1991 based on the works of Raoul Hausmann and Olga Rozanova.

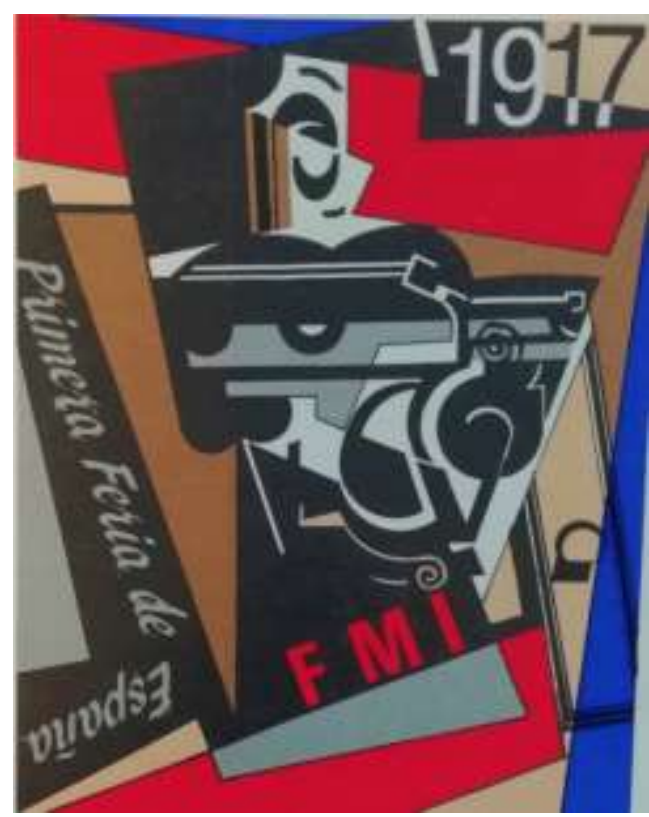

Fig. 12. Paco Bascuñán: Christmas greetings card on Juan Gris (Feria Muestrario Internacional de Valencia, 1989) - Arxiu Valencià del Disseny - 
It was in 2005 when Bascuñán took charge of his probably most ambitious work to date: the design of the complete visual environment for the theatrical play of Ubu roi-fig. 13 -, which included staging, audiovisual production, hand brochure, postcards, posters and costume design. The work of Bascuñán for Ubu roi was his closest experience to the Wagnerian sublime ideal of Gesamtkunstwerk, (total work of art). Bascuñán visualised a special connection between the postmodern times of the beginning of the twenty-one century and the hybridised, chaotic world devised by the author of the play, Alfred Jarry. Jarry was as much an artist as a writer and is regarded as an influential early avant-gardist from the end of the nineteenth century who created the imagery of Ubu:

Within the idea of a work as a space for hybridisation and cross-breeding, a place for heterogeneity, unstable in nature, the result of the viewer's projections, we find the essence of contemporary art, of which Jarry continues to be one of the most talented illustrators." (Eruli 196)

The strategy of Bascuñán consisted of keeping the fundamental Jarry's visual characters and forms while developing them further in a faithful way to the original author's disruptive poetics. Bascuñán upgraded technically the archaizing woodcuts of Jarry by treating them as multipurpose designs. Their brilliant colours, clear shapes and polished textures were applied to diverse formats and media like painting, printing, digital, sculpture, audiovisual or clothes. Bascuñan imbued the designs all together with a cybernetic, futuristic and dystopic look in his revision of Jarry's creation, merging past, present and future in his iconic images generating a feeling of time displacement. Bascuñán embodied "the idea that, as designers, we might begin to tackle the enormous opportunities to be had in staking claim to and shaping a new and unprecedented universe." (Helfland 123). 


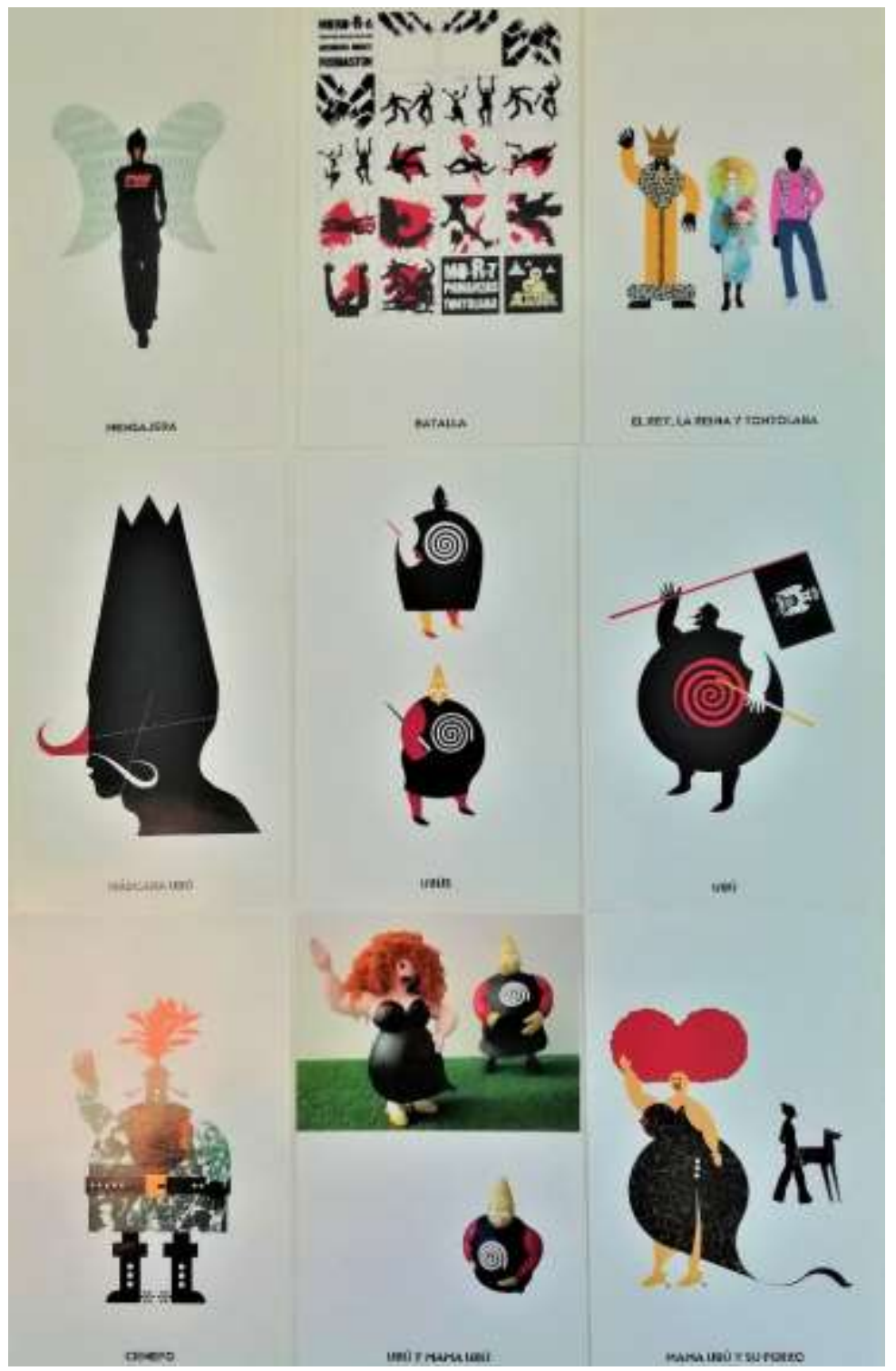

Fig. 13. Paco Bascuñán: Ubu roi postcards (Teatres de la Generalitat, 2005)

- Arxiu Valencià del Disseny -

\section{CONCLUSIONS}

Through the analysis of the works of seven designers, the most widespread conceptions of postmodern design can be questioned. Under a dualistic prism, design was at the forefront of the postmodernist surge but, beyond the oppositional categorizations and standardised images, postmodern design was not always a merely superficial or unsubstantial exercise. Postmodern design has not resigned from all the goals of Modernity. Neither was doomed to exhibit a lack of meaning and purpose. The ways by which some designers reintroduced iconic motifs in their creations invite us to consider that sometimes icons in design are not synonyms of expendable ornaments or an 
objectionable manifestation of the culture of spectacle. In the cases studied in this essay, the proliferation of icons as sources of inspiration - as well as essential components of the works - can coexist with a strong penchant for functionality and the craving for enhancing the expressive power of the objects.

Ambiguity, playfulness, uneasiness, bewilderment, humour, hybridisation, contradiction, historicisation, displacement, disorientation, questioning cultural hierarchies, putting in evidence ontologic assumptions and blurring conceptual boundaries deserve our attention as communicative strategies. Designed objects can be the subjects of hermeneutical-based approaches to interpreting the complexity of the messages they convey. All in all, the power of designed objects to configure the visual culture landscape and their influence on our habits triggered some still ongoing biopolitical implications.

\section{WORKS CITED}

Adamson, Glenn and Jane Pavitt: Postmodernism: Style and Subversion, 1970-1990. London: V \& A Publishing, 2011. 12-95.

Alcalde, Maxence: “L'art postmoderne comme idéologie réactionnaire. Un symptôme du rejet intellectuel de l'art contemporain". Marges 3 (2004): 97-107. Web. 9 August 2021.

Appadurai, Arjun. "Introduction: commodities and the politics of value". Appadurai, Arjun (ed.). The social life of things. Commodities in cultural perspective. Cambridge: Cambridge University Press, 1986. 3-63.

"Art-Industry". The I/lustrated Exhibition and Magazine of Art 21 1852: 331-332.

Bardzell, Shaowen, et al. "Critical Design and Critical Theory: The Challenge of Designing for Provocation". D/S 2012 June 11-15 (2012): 288-297. Web. 16 May 2021.

Bloom, Paul. "Intention, history and artifact concepts". Cognition 60 (1996): 1-29.

Bourdieu, Pierre. Distinction. A Social Critique of the Judgement of Taste. Cambridge, Massachusetts: Harvard University Press, 1984.

Carpenter, Merlin. The Outside Can't Go Outside. Berlin: Sternberg Press, 2018.

Certeau, Michel de. The Practice of Everyday Life. Berkeley: University of California Press, 1984.

Christensen, Michelle and Florian Conradi. Politics of Things. A Critical Approach through 
Design. Basel: Birkhäuser, 2019.

Clair, Jean. Hubris. La fabrique du monstre dans l'art moderne. Paris: Gallimard, 2012.

Crane, Walter. The Bases of Design. London: G. Bell and Sons Ltd., 1920.

Christensen, Michelle and Florian Conradi. Politics of Things. A critical approach through Dessing. Basel: Birkhäuser, 2019.

Eruli, Brunella. "An off centre space: Jarry the ymagier". De los nabis a la patafísica. Alfred Jarry. Valencia: IVAM-Generalitat Valenciana, 2001. 194-197.

Flusser, Vilém. The Shape of Things. A Philosophy of Design. London: Reaktion Books, 1999.

Francalanci, Ernesto. Estética de los objetos. Madrid: Machado, 2010.

Galán, Julia. Paco Bascuñán. Repertoris. Castelló: Universitat Jaume I-Ajuntament de Castelló, 2001.

Gámez, Carlos and Xiqi Yuwang. El interiorista y el extraño caso del señor lkea. Conversaciones entre interioristas, diseñadores y algún arquitecto. Valencia: CDICV-EASD Valencia, 2010.

Gimeno Martínez, Javier. José Juan Belda. Objectes i espais. Castelló: Universitat Jaume IAjuntament de Castelló, 2009.

Giordano, Dora. Cuestiones de diseño. Equilibrio inestable sobre campos imprecisos. Getafe: Experimenta Libros, 2020.

Gura, Judith. Postmodern design complete. London: Thames \& Hudson, 2017.

Güven, Yilmaz Burak. Postmodernism as an Interior Space Design Approach. Degree Thesis. Bilkent University. Ankara, 1993.

Harvey, David. The Condition of Postmodernity. Oxford: Blackwell Publishers, 1992.

Helfland, Jessica. "Dematerialization of Screen Space". Graphic design theory. Readings from the field, edited by Helen Amstrong. New York: Princeton Architectural Press, 2009. 119-123.

Hervás y Heras, Josenia and Silvia Blanco Agüeira. "Female Designers in Spanish Transition to Democracy, 1982-1992: from decoration to avant garde production". Proyecta 56: An Industrial Design Journal 1 (2021): 38-49. Web. 2 September 2021.

Julier, Guy. "From Visual Culture to Design Culture". Design/ssues 22.1 (2006): 64-76. Web. 
5 July 2021.

Latour, Bruno. We Have Never Been Modern. Cambridge, Massachusetts: Harvard University Press, 1993.

Lipovetsky, Gilles and Jean Serroy. La estetización del mundo. Vivir en la época del capitalismo artístico. Barcelona: Anagrama, 2015.

Maher, A. Gabriel. "Wonderment domastication”. Social matter, social design. For good or bad, all design is social, edited by Jan Boelen and Michael Kaethlers. Amsterdam: Valiz, 2020. 43-51.

Manzini, Ezio. “Design Culture and Dialogic Design”. Design/ssues 32.1 (2016): 52-59. Web. 5 July 2021.

Marín, Joan Manuel. “Doce años de creatividad (2008-2018): crisis e internacionalización del diseño industrial en el contexto valenciano". Entre la crisis, la resistencia y la creatividad. Los diez últimos años del arte valenciano contemporáneo (2008-2018), edited by Román de la Calle. Valencia: Universitat Politècnica de València, 2020. 195-219.

Martínez Martínez, C. Rafael. Lola Castelló. Belleza y función. Castelló: Universitat Jaume I - Ajuntament de Castelló, 2021.

Martínez, Rodrigo, Javier Pastor and Alberto López. "The Mediterranean influence in the Spanish design identity". ArD/n, Arte, Diseño e Ingeniería 3 (2014): 36-60. Web. 2 July 2021.

Papageorgiou, Theofanis, Panayotis G. Michaelides and Dieter Bögenhold. "Veblen and Bourdieu on Social Reality and Order: Individuals and Institutions". Journal of Economic Issues 54.3 (2020): 710-731.

Pelta, Raquel. "Paco Bascuñán. For ever". Laudatio speech for the posthumous inception of Paco Bascuñan in the San Carlos Academy of Fine Arts of Valencia. La deriva tipográfica, Paco Bascuñán. Valencia: Real Academia de Bellas artes de ValenciaCampgràfic, 2009. 25-33.

Power, Kevin. "Postmodernism in Art". El papel y la función del arte en el siglo XX. Vol. I, edited by Paloma Rodríguez-Escudero, Xabier Sáenz de Gorbea and Ane Olaizola. Bilbao: Universidad del País Vasco, 1994. 147-160. 
Rambla, Wenceslao. Vicent Martínez o el disseny de mobiliari en el marc de Puntmobles. Castelló: Universitat Jaume I-Ajuntament de Castelló, 2005.

Sudjic, Deyan. The Language of Things. New York: Penguin Books, 2009. Web. 10 July 2021.

Val Segarra Oña, María del. Creación de un modelo para el estudio de la competitividad de un sector industrial tradicional: aplicación al sector del mueble de hogar de la Comunidad Valenciana. PhD dissertation. Universidad Politécnica de Valencia, Valencia, 2003.

Veblen, Thorstein. The Theory of the Leisure Class. An Economic Study on Institutions. New York: B. W. Huebsch, 1918. 